\title{
WALKA O DUSZE W CULTURA INGENIORUM ANTONIO POSSEVINA SJ
}

\begin{abstract}
Streszczenie
Artykuł zapowiada i omawia pierwsze polskie wydanie dzieła Antonio Possevina SJ Cultura ingeniorum oparte na uwspółcześnionym tłumaczeniu tekstu autorstwa Krystyny Remerowej wydania pierwszej księgi Bibliotheca selecta, z 1604 r. Akcentuje kontekst historyczny, opisuje kluczowe wątki, sygnalizuje kontrowersje m.in. związane $\mathrm{z}$ rozumieniem cenzury zakonnej jako regulatora komunikacji piśmienniczej. Na przełomie XVI i XVII wieku o. A. Possevino był uczestnikiem wydarzeń zmieniających bieg historii, a przede wszystkim obraz ówczesnego społeczeństwa, chciał wpływać na te zmiany m.in. poprzez właściwe według niego i zalecane przez zakon jezuitów, zwłaszcza po Soborze Trydenckim, ukierunkowanie młodzieży, kształcenie jej poprzez odpowiednio dobraną lekturę i zajęcia fizyczne, szlifowanie (paideia) talentów na miarę ich możliwości, zawsze ku chwale Boga. W tym zakresie tekst może być przyczynkiem do interpretacji w perspektywie paradygmatów edukacji medialnej. Artykuł prezentuje dzieło A. Possevina jako pracę obrazującą dylematy epoki wynikające też z nakazów władz kościelnych i zakonnych budzących różne kontrowersje. Jest to tekst dojrzałego duchowo autora, przekonanego o słuszności wybranej drogi, czasem bezwzględnie wspierającego poczynania kontrreformacji.
\end{abstract}

Słowa kluczowe: cenzura; książka; edukacja medialna; reformacja; jezuici

\section{Wstęp}

Ruch humanistyczny zapoczątkowany we Włoszech w XV wieku najpierw jako ruch filologiczny, światopoglądowy, a także filozoficzny przyniósł zaskakująco zmieniony odbiór obrazu rzeczywistości, dał też nieskończenie wiele możli-

* Dariusz Kuźmina - prof. dr hab. nauk humanistycznych; Wydział Dziennikarstwa, Informacji i Bibliologii, Uniwersytet Warszawski

e-mail: d.kuzmina@uw.edu.pl https://orcid.org/0000-0002-7620-0952 
wości. W przeciwieństwie do średniowiecza, które gloryfikowało Boga, renesans kierował całą uwagę ku wartościom uniwersalnym i - wbrew naukom duchownych o marności świata i pogardzie dla doczesności - dał nowe spojrzenie na człowieka, moralność, religię, nauki ścisłe, sztukę. Był to czas rozkwitu oraz wzrostu nauki i sztuki.

Wynalezienie prasy drukarskiej stanowiło tu czynnik kluczowy, niezwykle ważny w upowszechnianiu kultury w XV i XVI wieku. Ułatwiło dostęp do druków, a tym samym do wiedzy, stworzyło nowe możliwości szybszego dotarcia do odbiorcy. Jak pisał Francis Bacon w Novum Organum wydanym w 1620 r.:

Warto dalej zwrócić uwagę na moc, wydolność i następstwa wynalazków, co w niczym nie występuje tak wyraźnie, jak w tych trzech odkryciach, które były nieznane starożytnym, a których początki, chociaż niedawne, są nieznane i nikomu nie przyniosły sławy; mamy na myśli wynalazek druku, prochu strzelniczego i busoli morskiej. Te trzy bowiem wynalazki zmieniły całkowicie oblicze rzeczy i stosunki na świecie ${ }^{1}$.

Narastające spory religijne i dyskusje wokół koncepcji, roli i władzy Kościoła stawały się coraz większym problemem. Wystąpienia Marcina Lutra czy Jana Kalwina i cały ruch reformatorski nie zdobyłyby tak szybko wielkiego poparcia, gdyby nie nagłaśniający je druk. Roli książki drukowanej w rozwoju kultury europejskiej nie da się przecenić.

Protestanci i katolicy dążyli do przedstawienia swoich doktryn, warsztaty drukarskie każdej ze stron mogły wydatnie pomóc, oferując druk i jego rozpowszechnianie. Zwolennicy myśli reformatorskiej wspierali finansowo wydania tekstów nowych wspólnot wyznaniowych. Władze Kościoła katolickiego musiały zareagować, bo choć tradycja kontrolowania i aprobowania pism

(...) sięga początków piśmiennictwa chrześcijańskiego, a pierwszymi cenzorami, czyli osobami badającymi oraz oceniającymi teksty pod względem ich zgodności z zasadami wiary i moralności byli papieże oraz biskupi²,

to w przypadku książek drukowanych sytuacja zaczęła wymykać się spod kontroli. Dotychczas stosowano cenzurę prewencyjną (censura praevia), zwaną również uprzednią, gdyż obejmowała książki i pisma przed ich opublikowaniem. Kolejni papieże, w tym najdobitniej Leon X (1513-1521) w wydanej w 1515 r. nowej konstytucji Inter sollicitudines zapisał:

${ }^{1}$ F. Bacon, Novum Organum, [Księga pierwsza] aforyzmów o tlumaczeniu przyrody i o królestwie człowieka, https://sady.up.krakow.pl/filnauk.bacon.norganum.htm (dostęp: 25.10.2021).

2 „Już pod koniec IV wieku św. Ambroży (340-397) wysyłał swoje dzieła do biskupa Sabina z Piacenzy $(+420)$ z prośbą o lekturę i ocenę tekstów przed ich opublikowaniem. W jednym z listów skierowanych do biskupa św. Ambroży pisał: «(...) proszę cię, abyś był sędzią tych pism (...). Pragnę bowiem nie tyle, aby moje dzieła, które niekiedy publikuję, były przez ciebie czytane, lecz aby zostały poddane osądowi twojego wyroku (...). Przeto w duchu życzliwości przyjmij postawę krytyczną i przebadaj wszystko szczegółowo» [Ambroży z Mediolanu, 1997, s. 238-239]. Również św. Augustyn (354-430) przedstawił swoje dzieło Libri quatuor contra duas epistolas Pelagianorum papieżowi Bonifacemu I (418-422), aby ten dokonał przeglądu i, jeśli zajdzie taka potrzeba, także poprawy". Cyt. za: A. Muc, Cenzura uprzednia w prawodawstwie kościelnym-zarys problematyki, „Bibliotheca Nostra”, (2013) nr 2, s. 38. 
Rozciągnęliśmy swoją pieczę nad sprawą drukowania książek, aby to, co zostało wynalezione na chwałę Bożą, dla pomnożenia wiary oraz dla upowszechnienia dobrej sztuki, nie przeciwstawiło się swemu celowi przynosząc szkodę zbawieniu chrześcijan ${ }^{3}$.

To jednak wciąż było za mało.

Celem artykułu jest ukazanie znaczenia dzieła (przygotowywanego do wydania w języku polskim) Antonio Possevina SJ, Cultura ingeniorum, w budowaniu podstaw szkolnictwa katolickiego i zasad wydawania książek, które stałyby się orężem $\mathrm{w}$ walce $\mathrm{z}$ reformacją.

\section{Walka Kościoła katolickiego z protestantyzmem}

W czasach narastającego konfliktu i w niezwykle trudnych dla Kościoła katolickiego warunkach został zwołany Sobór Trydencki. Historycy kultury pisząc o nim, akcentują fakt, że był to

pewien punkt zwrotny, przełom, który wyraziście oddziela jedną formację kulturową od następnej. (...) Rozpoczęcie Soboru Trydenckiego można zatem uznać za swoistą cezurę, domykającą etap swobodnych poszukiwań na gruncie literatury wczesnochrześcijańskiej, nie w tym jednak sensie, aby w trakcie trwania obrad soborowych dokonał się jakiś gwałtowny przełom. Obrady te zasygnalizowały jednak szereg istotnych zmian, które procesualnie dokonały się na gruncie nowożytnej kultury religijnej ${ }^{4}$.

\section{Wpływ soboru}

na europejską kulturę religijną można wręcz uznać za początek nowej koncepcji humanizmu, nie zrywającej wprawdzie z humanizmem renesansowym, ale nakierowującą tendencje charakterystyczne dla XVI wieku na nowe tory. O ile przed Soborem dominował nastrój swobodnych poszukiwań na gruncie różnych znaczeń Pisma Świętego oraz interpretacji początków i rozwoju doktryny kościelnej, o tyle czasy potrydenckie naznaczone już były polemiką o wyraźnie zarysowanych ramach konfesyjnych. Nadrzędna zasada soborowa, owe salus animarum suprema lex esto, przełożyła się również na nowe rozumienie ideału ad fontes, a ściślej - poszukiwania starożytnych źródeł kultury chrześcijańskiej5.

Dzieje tego soboru ${ }^{6}$ to w istocie historia ówczesnej Europy. Mimo wielu przeszkód prowadzony wskazówkami ówczesnych papieży, udzielanymi za pośred-

${ }^{3}$ H. Misztal, Cenzura uprzednia pism i druków w Kościele zachodnim (studium historyczno-prawne), Lublin 2001, s. 35; Muc, Cenzura uprzednia w prawodawstwie kościelnym, s. 40.

${ }^{4}$ M. Prejs, Humanizm potrydencki i nowy model kultury katolickiej (manieryzm czy barok?), w: Humanistyczne modele kultury nowożytnej wobec dziedzictwa starożytnego, red. M. Prejs, Warszawa 2010, s. 153, 156-158.

${ }^{5}$ M. Gołębiowski, Wpływ Ojców Kościoła na prozę staropolska przełomu XVI i XVII wieku. Analiza wybranych utworów, praca doktorska, UJ 2020, https://ruj.uj.edu.pl/xmlui/bitstream/handle/item/276479/golebiowski_wplyw_ojcow_kosciola_na_proze_staropolska_2020.pdf?sequence $=1 \&$ isAllowed=y (dostęp: 29.10 .2021$)$.

${ }^{6}$ „Rozpoczęty 13 grudnia 1545 i zakończony 4 grudnia 1563 r., ciągnął się lat z górą 18, z których 15 należy wpisać na konto czterech wielkich przerw. Obrady toczyły się w trzech okresach. Pierwszy okres liczył 10 posiedzeń publicznych, drugi 6 (11-16), trzeci 9 (17-25). Każde zwołanie 
nictwem wielkich legatów: Reginalda Pole'a (1500-1558), Marcello Cerviniego (1501-1555), Giovanniego Girolamo Morone'a (1509-1580) i Jana Marię del Monte (1487-1555), dokonał wielkiego dzieła, do dnia dzisiejszego stanowiącego „magnam chartam Kościoła Katolickiego"7. Notabene w trzecim okresie soboru, wśród pięciu legatów papieskich, znajdował się kard. Stanisław Hozjusz (1504-1579), bp warmiński i dyplomata kościelny. Przypisuje mu się zradykalizowanie obrad i to, że „sobór z kierunku humanistycznego, (jaki cechował biskupów włoskich w pierwszej połowie XVI w.) podczas pierwszego okresu, nawrócił w trzecim okresie do bardziej scholastycznego traktowania spraw"8.

Sobór miał doprecyzować kierunki rozwoju nauki katolickiej tak, aby powstrzymać dalszy rozlew herezji. W jego dokumentach można znaleźć wątki antyreformacyjne, nie są jednak dominujące. Odrzucił wprawdzie główne idee reformacji, wyznaczając tym samym program kontrreformacji, a poprzez wydanie szeregu dekretów zainicjował wewnętrzną reformę Kościoła rzymskokatolickiego. Skupiając się na dyscyplinie kościelnej, podkreślił utrzymanie celibatu duchownych, wydał polecenie utworzenia w każdej diecezji seminariów duchownych, a także zaakcentował konieczność wprowadzenia indeksu ksiąg zakazanych ${ }^{9}$. Tworząc go, władze kościelne narzuciły cenzurę represyjną. Uporządkowano wówczas szczegółową procedurę badania cenzorskiego. Został odnowiony dekret Soboru Laterańskiego V utrzymujący zakaz rozpowszechniania dzieł bez aprobaty. Sobór Trydencki przedstawił też stanowisko Kościoła odnośnie książek napisanych przez heretyków i tych częściowo zawierających błędy ${ }^{10}$. Najważniej-

soboru (1544, 1550 i 1560) poprzedziła długa i żmudna praca - zarówno na polu kościelnym, jak i dyplomatyczno-politycznym, ze względu na ścisłe połączenie wypadków polityczno-wojennych z wypadkami religijnymi i z ogólnym ruchem idei”. Cyt. za: A. Petrani, Reforma trydencka, „Prawo Kanoniczne", 7 (1964) nr 3/4, s. 2.

${ }^{7}$ Tamże; A. Nowicka-Jeżowa, Pokolenia trydenckie między tradycją a wyzwaniami przyszłości, w: Formowanie kultury katolickiej w dobie potrydenckiej. Powszechność i narodowość katolicyzmu polskiego, red. J. Dąbkowska-Kujko, Warszawa 2016, s. 24-31.

${ }^{8}$ Petrani, Reforma trydencka, s. 3.

${ }^{9}$ Index librorum prohibitorum obowiązywał w latach 1559-1966, został zniesiony po Soborze Watykańskim II przez papieża Pawła VI (1963-1978).

${ }^{10}$ „Książki, które w swej zasadniczej części były poprawne, a tylko ubocznie zawierały błędy heretyckie, zabobony i praktyki wróżbiarskie, mogły być po oczyszczeniu z nich, dozwolone katolikom. Po raz pierwszy uregulowano wówczas kwestię pozwolenia na druk na terenie różnych klasztorów. Zakonnicy poza uzyskaniem aprobaty właściwego biskupa zostali zobligowani do otrzymania zgody bezpośredniego przełożonego, który miał obowiązek zbadania dzieła według wymagań konstytucji danego zakonu. Wprowadzono także nowy przepis nakazujący cenzorom przechowywanie jednego autentycznego i podpisanego przez autora egzemplarza sprawdzonego tekstu. Domy i miejsca, gdzie drukowano i przechowywano książki miały być często wizytowane przez wysłanników biskupa i inkwizytora. Dodatkowo do biskupa i inkwizytora należało się zwracać, gdy ktoś chciał sprowadzać książki do jakiejś miejscowości, pożyczać do czytania lub sprzedawać, chyba że publicznie było wiadomo, że tytuł jest dozwolony przez kościół”. Cyt. za: Misztal, Cenzura uprzednia pism i druków $w$ Kościele zachodnim, s. 42-43. 
szymi instancjami w sprawach cenzury kościelnej stały się Kongregacja Inkwizycji i Kongregacja Indeksu ${ }^{11}$.

Reformacja rozkwitała, rozlewała się na całą Europę z niespotykaną siłą, a dokonujące się przemiany były poważne. W XVI wieku jezuici „byli jedyną siłą intelektualną, która mogła przeciwstawić się protestantyzmowi i prowadzić z nim polemiki" ${ }^{2}$. W 1539 r. Ignacy Loyola przedstawił do zatwierdzenia Stolicy Apostolskiej Formula Instituti Societatis Iesu ${ }^{13}$, który zaaprobowany przez papieża Pawła III (1534-1549) w 1540 r. znalazł się w dokumentach powołujących do życia zakon. Jednym z podstawowych zadań nowej wspólnoty, oprócz wspierania papieża $\mathrm{w}$ najtrudniejszych zadaniach, było „rozszerzanie wiary przez posługę słowa Bożego"'14. Działalność jezuitów początkowo skoncentrowana na walce ideologicznej z reformacją skutkowała również stworzeniem podstaw systemu szkolnictwa. Na terenach zagrożonych wpływami reformacji zakładali szkoły katolickie i głosili płomienne kazania. Siecią swych placówek pokryli nie tylko Europę, z działalnością misyjną udali się również na inne kontynenty. W Polsce jezuici pojawili się za sprawą bp. S. Hozjusza w 1564 r. ${ }^{15}$

W statutach dla członków zakonu wypracowanych na polecenie papieża, Constitutiones Societatis Jesu, w części dotyczącej wychowania, zawarli podstawy pedagogiki jezuickiej, w której położyli nacisk na studium teologii i filozofii pod patronatem Arystotelesa i św. Tomasza z Akwinu. W 1586 r. powstała pierwsza wersja Ratio atque institutio studiorum S.J., ostateczny kształt uzyskała 8 stycznia 1599 r. Hasłem jezuickiej pedagogiki stała się ,uczona i wymowna pobożność”16. Warto zwrócić uwagę na fakt, że ich kolegia i uniwersytety bogato wykorzystywały doświadczenia innowacyjnego szkolnictwa humanistycznego, którego

korzeni należy szukać w szkołach niderlandzkich, prowadzonych przez Braci Wspólnego Życia (ich najsłynniejszym wychowankiem był Erazm z Rotterdamu, a także w szkolnictwie protestanckim z jego najbardziej miarodajnym re-

${ }^{11}$ Kongregację Inkwizycji założył papież Paweł IV (1555-1559) w 1542 r. konstytucją Licet ab initio. Kongregację Indeksu powołał papież Pius V (1566-1572) w 1571 r., zajmowała się sprawą aprobaty, druku i ewentualną korektą książek. Por. Misztal, Cenzura uprzednia pism i druków w Kościele zachodnim, s. 45.

${ }^{12} \mathrm{~S}$. Litak, Jezuici na tle innych zakonów męskich w Polsce w XVI-XVIII wieku, w: Jezuici a kultura polska. Materiaty sympozjum z okazji jubileuszu 500-lecia urodzin Ignacego Loyoli (14911991) i 450-lecia powstania Towarzystwa Jezusowego (1540-1990), Kraków, 15-17 lutego 1991 r., red. L. Grzebień, S. Obirek, Kraków 1993, s. 197; D. Kuźmina, Ksiązka religijna w czasach reformacji i kontrreformacji w Rzeczypospolitej XVI i XVII w. „Studia Ełckie”, 8 (2006) s. 158.

${ }^{13}$ W.V. Bangert, A History of the Society of Jesus, Saint Louis 1986.

${ }^{14}$ Formula Instytutu Towarzystwa Jezusowego, w: I. Loyola, Pisma wybrane. Komentarze, oprac. M. Bednarz SJ, współpr. S. Filipowicz SJ, R. Skórka SJ, t. 1, Kraków 1969, s. 454. Cyt. za: M. Kuran, Rola szkolnictwa jezuickiego w ksztaltowaniu wspólnoty europejskiej, „Acta Universitatis Lodziensis. Folia Litteraria Polonica”, 13 (2010) s. 36.

${ }^{15}$ Kuran, Rola szkolnictwa jezuickiego w kształtowaniu wspólnoty europejskiej, s. 38.

${ }^{16}$ B. Natoński SJ, Szkolnictwo jezuickie w Polsce w dobie kontrreformacji, w: Z dziejów szkolnictwa jezuickiego w Polsce. Wybór artykułów, Kraków 1994, s. 35. 
prezentantem, Janem Sturmem). Koncepcja zaś szkolnictwa wyższego oparta została na tzw. modus parisiensis ${ }^{17}$.

Jak pisał jeden z ojców Kościoła św. Hilary z Poitiers (ok. 315-367) w De Trinitate:

Kościół, gdy jest prześladowany - rozkwita, gdy jest gnębiony - rośnie, gdy się go lekceważy - odnosi sukcesy, zaczepiony - zwycięży, gdy jest oskarżany pogłębia wiedzę, a wreszcie wtedy mocno stoi, gdy zdaje się być pokonany ${ }^{18}$.

Kościół walczył, a jezuici byli jego zbrojnym ramieniem.

Do końca XVI wieku Towarzystwo Jezusowe prowadziło 11 szkół w Rzeczypospolitej i jedną w Siedmiogrodzie. Jezuici zarządzali pięcioma seminariami diecezjalnymi, dwoma papieskimi, trzema konwentami szlacheckimi oraz bursami dla ubogich, które tworzono przy prawie każdym kolegium. Najważniejszym ich dziełem było powołanie do istnienia Akademii w Wilnie, która stała się symbolem ich rosnącej potęgi w Polsce. Tak intensywny rozwój placówek dydaktycznych wymagał dobrego przygotowania nauczycieli, na co w swoich tekstach szczególny nacisk kładł A. Possevino ${ }^{19}$.

\section{Antonio Possevino SJ}

Jednym z czołowych przedstawicieli ruchu kontrreformacyjnego był A. Possevino SJ (1533-1611) ${ }^{20}$, teolog i jeden z najwybitniejszych dyplomatów swoich czasów, doskonały mówca, bezwzględnie posłuszny papieżowi. Podejmowane przez niego misje, w większości skuteczne, miały znaczenie dla dziejów Moskwy, Siedmiogrodu, Szwecji, Francji, Italii i Rzeczpospolitej. Stan badań nad jego dzia-

${ }^{17}$ L. Piechnik, „Ratio studiorum”. Fundament dziatalności edukacyjnej i naukowej jezuitów, w: Wkład jezuitów do nauki i kultury w Rzeczypospolitej Obojga Narodów i pod zaborami, red. I. Stasiewicz-Jasiukowa, Kraków 2004, s. 70-72. Cyt. Za: Kuran, Rola szkolnictwa jezuickiego w ksztaltowaniu wspólnoty europejskiej, s. 42; A. Górecki, O jezuickiej Ratio studiorum, „Christianitas", (2014) nr 58, s. 61.

${ }^{18}$ Św. Hilary z Poitiers, De Trinitate. I. VII. 4. Patrol. Lat. X. 202. Cyt. za: „Wiadomości Archidiecezjalne Warszawskie", 17 (1927) nr 1, s. 15, http://mbc.cyfrowemazowsze.pl/Content/63135/ 00068107-Wiadomosci\%20Archidiecezjalne\%20warszawskie\%201927\%20nr\%201-P1873.pdf (dostęp: 24.03.2020).

${ }^{19}$ Natoński, Szkolnictwo jezuickie w Polsce w dobie kontrreformacji, s. 45.

${ }^{20}$ Antonio Possevino SJ (ur. 12 VII 1533 w Mantui, zm. 16 II 1611 w Ferrarze), kaznodzieja, w 1. 1573-1577 sekretarz gen. zakonu Everardo Mercuriana, w 1. 1577-1580 poseł papieski do króla Szwecji Jana III; w 1. 1581-1582 negocjował w Moskwie zawarcie pokoju między Iwanem Groźnym i Stefanem Batorym; organizował seminaria papieskie w Braniewie, Wilnie, Rydze, Dorpacie i Kolozsvárze. Był doradcą Stefana Batorego. Od 1587 wykładał w Padwie. Zob. L. Balsamo, Antonio Possevino S.I. bibliografo della Controriforma e diffusione della sua opera in area anglicana, Firenze 2006; Ł. Burkiewicz, Sylwetka o. Antonia Possevina SJ (1533-1611), w: Antonio Possevino SJ (1533-1611). Życie i dzieło na tle epoki, red. D. Quirini-Popławska, Kraków 2012, s. 155-183. 
łalnością jest dosyć szeroki, oprócz monografii ${ }^{21}$ jest dostępnych wiele artykułów przyczynkowych $^{22}$.

Hieronim Fokciński postulując przygotowanie podsumowania literatury polskiej na temat zakonnika, zwrócił uwagę na potrzebę wykonania szczegółowej inwentaryzacji materiałów zgromadzonych na mikrofilmach i w zasobie repertoriów Papieskiego Instytutu Studiów Kościelnych w Rzymie ${ }^{23}$.

A. Possevino pochodził z Mantui. Jego rodzina zmieniła nazwisko z Caliani na Possevino ${ }^{24}$, co lata później było źródłem podejrzeń o pochodzenie żydowskie i przyczyniło się do problemów jezuity z cenzurą i władzami zakonu. Do czasu utraty zaufania papieża Sykstusa V (1585-1590) i generała zakonu Klaudiusza Aquavivy (1543-1615) jego działania budziły podziw. Był jednak postacią kontrowersyjną, zarzucano mu brak cierpliwości i pokory ${ }^{25}$.

\section{Bibliotheca selecta de ratione studiorum}

W czasie przymusowego pobytu w Padwie A. Possevino przygotował i wydał w 1593 roku dzieło wartościujące piśmiennictwo zaaprobowane przez Kościół katolicki - Bibliotheca selecta: qua agitur de ratione studiorum in historia, in disciplinis, in salute omnium procuranda. Wykorzystał istniejący już wcześniej typ książki-katalogu autorów i ich dzieł. Wybór podporządkował naczelnemu celowi, jakim było w owym czasie nieustanne wzmacnianie roli Kościoła katolickiego m.in. poprzez

dostarczenie nauczycielom szkół jezuickich we wszystkich krajach określonej metody nauczania oraz interpretowania dotychczasowego dorobku kulturalnego Europy od czasów antyku. Celem i miarą tej interpretacji miała być rozumiana szeroko przez Possewina pobożność (pietas), w której granicach zamy-

${ }^{21}$ J. Dorigny, La vie du Père Antoine Possevin de la Compagnie de Jésus, Paris 1712; L. Karttunen, Antonio Possevino. Un diplomate pontifical au XVIe siècle, Lausanne 1908; A. Hofmann, Antonio Possevinos Bemühungen um die sogenannten Nordischen Päpstlichen Seminare 15781585, Koblenz 1929; S. Polčin, Une tentative d'Union au XVIe siècle. La mission religieuse du Père Antoine Possevin S.J. en Moscovie, Rome 1957; Balsamo, Antonio Possevino S.I. bibliografo.

22 J.P. Donnelly, Antonio Possevino and Jesuits of Jewish Ancestry, „Archivum Historicum Societatis Iesu", 55 (1986) s. 3-31; tenże, Antonio Possevino as Papal Mediator between Emperor Rudolf II and King Stephan Báthory, „Archivum Historicum Societatis Iesu”, 69 (2000) s. 3-56; tenże, Antonio Possevino: From Mercurian's Secretary to Papal Legate in Sweden, w: The Mercurian Project. Forming Jesuit Culture, 1573-1580, red. T. McCoog, Rome 2004, s. 323-349. Za: Burkiewicz, Sylwetka o. Antonia Possevina SJ, s. 156.

${ }^{23}$ „Repertoria za okres od kwietnia 1578 do kwietnia 1587 - wykazują istnienie 1200 dokumentów”. Cyt. za: H. Fokciński, Polonica Posseviniana, w: Antonio Possevino SJ (1533-1611). Życie i dzieło na tle epoki, s. 196-197.

${ }^{24}$ Donnelly, Antonio Possevino and Jesuits, s. 4. Za: Burkiewicz, Sylwetka o. Antonia Possevina SJ, s. 158.

${ }^{25}$ S. Obirek, Antonio Possevino SJ i jego misja do Moskwy, „Nasza Przyszłość”, 89 (1998) s. 122. Za: Burkiewicz, Sylwetka o. Antonia Possevina SJ, s. 181. 
kały się nie tylko zasady religii katolickiej, ale i interesy Kościoła rzymskiego i zakonu jezuitów ${ }^{26}$.

Było przeznaczone dla jezuickich wychowawców i przewodników duchowych młodzieży. Uważa się, że stanowiło odpowiedź na Bibliotheca universalis, sive catalogus omnium scriptorum locupletissimus, in tribus linguis, latina, graeca et hebraica wydaną w 1545 r. przez Konrada Gesnera (1516-1565), uważaną za dzieło przełomowe kultury renesansowej pierwszej połowy XVI wieku. A. Possevino w swojej publikacji zawarł szczegółowe instrukcje dotyczące podporządkowania nauczania, rozumianego jako wszechstronne kształtowanie (paideia ${ }^{27}$ ), zaleceniom Soboru Trydenckiego. Stworzył plan działania służący kontrreformacji, kanon normatywny dla konfrontacji teologicznej i doktrynalnej.

K. Gesner wymieniał wszystkich autorów, bez względu na wyznanie, stąd tytuł Bibliotheca universalis. W Bibliotheca selecta są odnotowane książki i autorzy z różnych dziedzin wiedzy, jednak według założonych z góry kryteriów.

Dzieło Possevina miało bowiem w zamierzeniu jego autora być nie tylko informatorem i poradnikiem bibliograficznym, to jest spełniać rolę naukową, ale przekazując czytelnikom wskazówki postępowania moralnego i interpretowania tekstów różnych książek, stać się ważkim instrumentem ideologicznym. (...) Byli to jednak autorzy specjalnie dobrani pod kątem ich prawowierności katolickiej i przykładności moralnej (meliores et selectiores auctores), nie zakwestionowani przez potrydencki indeks ksiąg zakazanych ${ }^{28}$.

A. Possevino, obok radykalnego Roberta Bellarmina (1542-1621), który w Disputationes de controversiis christianae ${ }^{29}(1586)$ przywołał kontrargumenty służące w sporach doktrynalnych z heretykami, choć potępiał ich działania, uważał, iż powinno się ze spokojem odpierać tezy przeciwników, prowadzić z nimi dialog, a nie zwalczać siłą. Wskazał nawet teksty starożytnych, po które chrześcijanin może sięgać bez oporów. Obok właściwej edukacji młodzieży widział katechizację jako podstawową metodę obrony wiary ${ }^{30}$.

${ }^{26}$ T. Bieńkowski, ,Bibliotheca selecta de ratione studiorum” Possewina jako teoretyczny fundament kultury kontrreformacji, w: Wiek XVII - kontrreformacja - barok. Prace z historii kultury, red. J. Pelc, Wrocław 1970, s. 294.

${ }^{27}$ J. Budzyński, Paideia humanistyczna, czyli wychowanie do kultury. Studium z dziejów klasycznej edukacji w gimnazjach XVI-XVIII wieku (na przyktadzie Ślaska), Częstochowa 2003, s. 26-29. Zob. też: W. Jaeger, Paideia. Formowanie człowieka greckiego, Warszawa 2001; J. Dąbkowska--Kujko, Jezuicka paideia, https://www.kul.pl/files/268/dabkowska_kujko_jezuicka_paideia.pdf, s. 164 (dostęp: 25.10.2021).

${ }^{28}$ Bieńkowski, ,Bibliotheca selecta de ratione studiorum”, s. 294.

${ }^{29}$ Balsamo, Antonio Possevino S.I, s. 11-18. Za: A. Bielak, Symbolica vitae Christi meditatio Tomasza Tretera jako siedemnastowieczna realizacja emblematycznych medytacji. Źródła graficzne i zamyst zbioru, „Terminus”, 20 (2018) z. 4 (49), s. 449-450.

${ }^{30}$ „Polecił drukować je [katechizmy] w różnych językach w tysiącach nakładu, sprzedawał je, rozdawał, gdzie tylko się znalazł, we Francji, we Włoszech, w Szwecji i w Polsce. W czasie pobytu w naszym kraju kazał wydać w drukarni akademickiej w Wilnie około 1000 katechizmów w języku estońskim, 1500 w języku ruskim, 1000 w litewskim”. Cyt. za: L. Grzebień, Antonio Possevino a sprawa katechizmów w językach narodowych, w: Antonio Possevino SJ (1533-1611). Życie i dzieto na tle epoki, s. 353. 
Dla reformatorów protestanckich, jak i jezuitów szkolnictwo było niezwykle istotne. Dostrzegali jego rolę w kształtowaniu wspólnoty europejskiej. Jak zaznaczył Pedro de Ribadeneira (1527-1611) w liście z 14 lutego 1556 r. skierowanym do króla Hiszpanii Filipa II: „zachowanie dobrej kondycji chrześcijaństwa i całego świata zależy od właściwego wychowania młodzieży"31.

Cultura ingeniorum, część Bibliotheca selecta, opublikowana osobno w Vicenzy, już w $1598 \mathrm{r}$. zawierała program działalności wychowawczej i kulturalnej jezuitów. Wierni w przekonaniu, że dobra literatura zwykle służy dydaktyce, program swojego studium gramatyki, retoryki, poetyki czy historii przygotowali na podstawie m.in. dzieł autorów greckich i rzymskich.

Bibliotheca selecta de ratione studiorum A. Possevina była wydawana w całości aż trzykrotnie, w Rzymie (1593), Wenecji (1603) i Kolonii (1607). Warto zaznaczyć, że Karol Estreicher w Bibliografii polskiej umieścił pracę jezuity pomiędzy polonikami, prawdopodobnie ze względu na dedykację dla króla Zygmunta III rozdziałów XII-XVIII ${ }^{32}$. Ostatecznie jednak, jak pisał T. Bieńkowski księga, kładąca teoretyczne podwaliny pod kulturę kręgu jezuickiego, znana i wznawiana z poprawkami w XVI i XVII wieku, nie spotkała się z zainteresowaniem historyków zajmujących się kontrreformacją ${ }^{33}$.

\section{De Cultura ingeniorum}

Pierwsza księga Bibliotheca selecta - Cultura ingeniorum, której polskim thumaczeniem wykonanym przez Krystynę Remerową dysponuję, ukazała się oddzielnie w Wenecji w 1604 r. ${ }^{34}$ Była przeznaczona dla uczniów kolegium jezuickiego w Kaliszu.

${ }^{31}$ J.W. O’Malley, Pierwsi jezuici, oprac. J. Kołacz, F. Rzepka, Kraków 2007, s. 299. Cyt. za: Dąbkowska-Kujko, Jezuicka paideia, s. 162.

${ }^{32}$ K. Estreicher, Bibliografia polska. Stulecie XV-XVIII w., cz. 3: lit. Pon-Q, ogólnego zbioru t. 25, Kraków 1913, s. 104, https://www.estreicher.uj.edu.pl/staropolska/baza/wpis/?sort=nazwisko_imie\&order $=1 \& \mathrm{id}=179783 \&$ offset $=0 \&$ index $=12$ (dostęp: 20.10 .2021$)$.

${ }^{33}$ Bieńkowski, ,, Bibliotheca selecta de ratione studiorum”, s. 291.

${ }^{34}$ Cultura ingeniorvm e Bibliotheca selecta Ant. Posseuini Societatis Iesu. Examen ingeniorum Io. Huartis expenditur. Quarta editio recognita et nunc emissa in gratiam nobilis Academiae Calissiensis in Polonia, Venetiis: apud Io. Baptistam Ciottum, 1604.

„De cultura ingeniorum jest tytułem siódmego rozdziału w pierwszej edycji Biblioteki, ale już $\mathrm{w}$ drugiej (Bibliotheca selecta de ratione studiorum, ad disciplinas, \& ad salutem omnium gentium procurandam, Venetiis: Altobello Salicato 1603) Possevino przerzucił ów rozdział na początek dzieła, połączywszy go dodatkowo z dwunastoma początkowymi rozdziałami pod jednym tytułem: De cultura ingeniorum. Duże zainteresowanie tym tekstem sprawiło, że ukazał się jego przekład włoski pt. Coltura degl'Ingegni (Vicenza: G. Greco 1598), ale pomieszano w nim numerację stron i rozdziałów, jak również dopisano nowe komentarze. Później ukazywały się już tylko edycje łacińskie: Venezia: G.B. Ciotti 1604; Parisii: C. Chappelet, 1605; Tarvisii: E. Deuchinum 1606; Köln, J. Gimnicus, 1610. Drugie wydanie In gratiam nobilis Academiae Calissiensis (1604) zadedykowane zostało pamięci prymasa Stanisława Karnkowskiego, natomiast czwarte (1606) carowi Rusi, Dymitrowi Iwanowiczowi, dzięki którego łaskawości w 1605 r. powstało w Moskwie kolegium jezuickie". Cyt. za: A. Dróżdż, Antonio Possevino (SJ) i jego rozprawa „Cultura ingeniorum” (1598) o wychowywaniu młodzieży z dala od druków zakazanych, „Roczniki Biblioteczne”, 54 (2010) s. 8. 
Składa się z pięćdziesięciu trzech rozdziałów, z których pierwszych siedem gloryfikuje zamysł Boga czyniącego świat poddanym, a człowieka na swój obraz i podobieństwo. Poprzez Biblię przekazał mu podstawowe prawdy wiary mające kształtować go i jego otoczenie. Wymagają one, zdaniem Possevina, interpretacji bardzo dobrych nauczycieli, którzy odpowiednio przygotowani merytoryczniei kierując się dobrą wolą, będą umieli przybliżać i thumaczyć prawdy objawione w $P i$ śmie św. Autor odwołuje się do wzorców starożytnych, podkreślając, że w czasach, gdy demokracja ateńska była zagrożona, zapraszano uczonych, by radami i nauczaniem wsparli utrzymanie wytworzonych wcześniej norm.

Jezuita pisząc swoje dzieło, poszukiwał dla Kościoła katolickiego zagrożonego reformacją oparcia i wzmocnienia ze strony najlepszych nauczycieli. Pedagodzy przygotowywani do szkół tworzonych i organizowanych na każdym poziomie edukacji mieli pomóc $\mathrm{w}$ osiąganiu celów nakreślonych m.in. przez Sobór Trydencki. W związku z tym zwrócił baczną uwagę (rozdz. XXIX) na właściwe budowanie warsztatu nauczyciela poprzez dobór publikacji, z jakich powinien korzystać i polecać uczniom. Odradził używania zbyt wzniosłego słownictwa w stosunku do pisarzy starożytnych, dystansując się do mówienia o boskości Platona czy Arystotelesa. Pogańscy myśliciele, jego zdaniem, powinni być cytowani, ale w odniesieniu do Biblii i druków zaakceptowanych przez Kościół katolicki tak, by wykładano tylko poprawną doktrynę i czyniono to z jednoznacznym wskazaniem rangi autorów z czasów dawnych i współczesnych podejmujących walkę $\mathrm{z}$ reformacją.

W kolejnych rozdziałach, odnosząc się przede wszystkim do Juana Huartego (ok. 1530-1588) i jego publikacji Examen de ingenios, a także dzieł filozofów starożytnych, wskazał, jakie nauki powinny być nauczane z uwzględnieniem zdolności uczniów wraz z sugestią, w jakim wieku przekazywana wiedza ma zdecydowanie większą szansę na szybkie i pełne przyswojenie. Dostrzegł np., że nauczanie języków obcych powinno się rozpoczynać jak najwcześniej. W rozdziale XV podjął polemikę z J. Huartem, wskazując, iż znajomość języków greckiego czy łacińskiego nie jest przeszkodą w rozumieniu treści z zakresu czystej filozofii czy teologii. Natomiast bardzo ważnym elementem kształcenia, pomocnym w rozumieniu treści najważniejszych, czyli boskich, jest podejmowanie rozmyślań i medytacji nad ważnymi zagadnieniami.

Można przypuszczać, że tak jak Bibliotheca universalis K. Gesnera paradoksalnie posłużyła inkwizytorom jako przewodnik przy wyborze ksiąg heretyckich, Examen de ingenios ${ }^{35} \mathrm{~J}$. Huartego został wykorzystany jako podstawa racjonalne-

${ }^{35}$ Examen de ingenios wydany 23 lutego 1575 r. w drukarni Juana Baptisty de Montoya, w Baezie odniósł sukces, a autorowi zaoferowano stanowisko wykładowcy uniwersytetu medycznego San Antonio de Portaceli de Sigüenza. Po pierwszych pięciu wydaniach książka została wciągnięta na indeks ksiąg zakazanych, w 1581 r. w Lizbonie, w 1583 r. w Madrycie. Indeks z 1584 r. wskazuje miejsca, które autor miał wykreślić albo przerobić. J. Huarte został zobowiązany do wprowadzenia poprawek zaleconych przez cenzurę do spraw herezji. Powstała wówczas nowa wersja tekstu, opublikowana po śmierci autora przez jego syna w 1594 r. „Książka z 356 stron editio princeps rozrosła się do 416 . W związku z tym, wydanie poprawione jest niemal nowym dziełem, różniącym się w stosunku do pierwotnej doktryny czy miejscami wręcz jej przeciwne". Cyt. za: J.C. Pastor, 
go wyboru książek pozwalających na doskonalenie zdolności jednostek z różnymi predyspozycjami, z pominięciem przez A. Possevina kwestii niewygodnych, np. takich jak ustalanie i utrwalanie warunków pozwalających na ograniczanie cech ujemnych jednostki, czym współcześnie zajmuje się eugenika, a co hiszpański autor opisał $\mathrm{w}$ ostatnich sześciu rozdziałach swojej pracy ${ }^{36}$. Jego dzieło oparte na intuicji, napisane ponad czterysta lat temu, wciąż inspirujące dla współczesnej psychologii, zawiera

obserwacje pedagogiczne, metodologiczne analizy różnych nauk dokonywane na podstawie ich przedmiotu, zakresu i ograniczeń, obronę determinizmu moralnego, rozważania na temat boskiej opatrzności i natury, rozważania na temat przypadku i przewidywania, a także wywody dotyczące natury języka oraz obronę używania języka ojczystego ${ }^{37}$.

J. Huarte wzorował się m.in. na pracach hiszpańskiego humanisty i pedagoga Juana Luisa Vivesa (1492-1540).

W rozdziale XXII A. Possevino wskazał jako wzór do naśladowania, założyciela swojego zakonu - św. Ignacego Loyolę, który poprzez medytację zrozumiał, że powinien dla dobra Kościoła, mimo osiągnięcia wieku ponad 30 lat, rozpocząć naukę języka łacińskiego i podjąć studia. Odnalezienie w każdym z uczniów jego zdolności i predyspozycji jest, zdaniem jezuity, jednym z najważniejszych zadań nauczyciela. W kolejnych fragmentach (rozdz. XV), odnosząc się przede wszystkim do pisarzy starożytnych (Arystoteles), podkreślił znaczenie prowadzenia procesu edukacji poprzez przygotowywanie wizualizacji treści i doboru tonacji głosu do przedstawianych zagadnień. Zaznaczył, że bardzo ważnym elementem jest egzekwowanie ćwiczeń zadanych uczniom (rozdz. XXX-XXXII) i prowadzenie $\mathrm{z}$ nimi lekcji $\mathrm{w}$ formule zadawania pytań (współczesne konwersatoria).

W rozdziałach XXXIV i XXXV A. Possevino podkreślił połączenie nauczania $\mathrm{z}$ dawaniem przez prowadzącego zajęcia przykładów $\mathrm{z}$ własnego życia religijnego, czyli np. uczynienie z częstego przyjmowania sakramentów argumentu na łatwiejszą naukę, jaśniejszy umysł. Zaakcentował potrzebę kształtowania pobożności, zachęcanie do medytacji i uczestnictwa w nabożeństwach katolickich, które mogą pomóc i zintensyfikować proces przyswajania wiedzy. Nauka i religia, zdaniem zakonnika, współpracują ze sobą, nie są sobie przeciwne, mogą być dla siebie inspiracją, zwłaszcza gdy właściwie dobieramy studiowane teksty.

Równie istotne w nauczaniu młodzieży jest, zdaniem autora Cultura ingeniorum, aby raczej nie zmuszać słuchaczy do notowania. Zauważa, iż uczeń nie zwraca wtedy uwagi na używanie poprawnej pisowni i stylu języka, a korzystanie z takich zapisów nie wnosi wiele, zwłaszcza gdy student wraca do nich po jakimś czasie (rozdz. XXVI). A. Possevino w swojej pracy (rozdz. XXXIX i XL) odniósł się również dość pobieżnie do opisania powstania Ratio studiorum. Skoncentrował się na bardzo ogólnych informacjach, m.in. procesie tworzenia dokumentu,

Juan Huarte Badanie umystów do nauk, w: Klasycy psychologii. Wprowadzenie do studiów psychologicznych, oprac. H.E. Lück, R. Miller, G. Sewz-Vosshenrich, Kraków 2008, s. 9-16.

${ }^{36}$ E.G. Gracía, A.M. Alonso, El „Examen de Ingenios” de Huarte de San Juan en la „Bibliotheca selecta” de Antonio Possevino, „Revista de Historia de la Psicología”, 25 (2003) nr (3-4), s. 395.

${ }^{37}$ Pastor, Juan Huarte. Badanie umystów do nauk, s. 13-14. 
akcentując tylko niektóre jego fragmenty. Służyło to podkreśleniu, iż jego własne dzieło o wiele bardziej uszczegóławia proces edukacji, jaki powinien zaistnieć we współczesnej szkole, w której należy przede wszystkim i to bezwzględnie zwalczać ruch reformatorski. Pracując nad Bibliotheca selecta, znał założenia powstającego Ratio studiorum. Chciał jednak podzielić się z czytelnikami własną analizą zagrożeń, jakie czekają na nauczycieli źle przygotowanych i słuchaczy, którym należy prezentować wiedzę, jak sądził, tylko w kontekście pobożności i przywiązania do Kościoła katolickiego.

Moim zdaniem powinna zostać przeprowadzona pełna analiza systemu szkolnictwa jezuickiego, począwszy od XVI wieku, porównanie Ratio studiorum i Bibliotheca selecta, $\mathrm{z}$ naciskiem na Cultura ingeniorum. Zestawienie tych fundamentalnych prac już wskazuje na ogromne znaczenie dla powodzenia misji zakonu analizy procesu dydaktycznego i metod prowadzenia zajęć. Ratio określa konkretne lektury i postawy, jakie powinny zaistnieć w kolegiach Towarzystwa Jezusowego. Jezuici prowadzili nauczanie w bardzo wielu miejscach w Europie i na świecie. Dokument z racji swojego znaczenia był adresowany do całej wspólnoty. Wskazuje np. jeden obowiązujący podręcznik gramatyki - Emmanuela Alvareza De Institutione grammatica libri tres wydany w Lizbonie w $1572 \mathrm{r}^{38}$ A. Possevino podpowiada czytelnikowi różne rodzaje książek. Podaje przykłady, podsuwa bardzo szczegółowe rozwiązania dotyczące prowadzenia zajęć i form prezentacji proponowanych przez nauczyciela. Te dwa dzieła wspierają się w zrozumieniu znaczenia i roli edukacji w czasach kontrreformacji. Ratio stworzone przez przedstawicieli zakonu z różnych prowincji było obowiązującym dokumentem, zaś praca jezuity mogła jedynie wspierać proces kształcenia, dlatego też $\mathrm{Cul}$ tura ingeniorum została zadedykowana uczniom kolegium kaliskiego.

$\mathrm{W}$ ostatnich rozdziałach pierwszej księgi jezuita zaprezentował własne stanowisko wobec wszystkich spraw związanych z tekstem, a więc: pisania, czytania, wydawania, upowszechniania, korekty, przechowywania, katalogowania, a szczególnie kwestii cenzury, której poświecił, w porównaniu z wyżej wymienionymi zagadnieniami, znacznie więcej miejsca. Zalecał szczególną ostrożność osobom podejmującym się cenzurowania i poprawiania dzieł innych pisarzy.

A jeśli domagam się takiej, czy to ostrożności czy wyrozumiałości od człowieka uczonego, cóż mi wypada myśleć o tych, którzy to, co jest dobrze powiedziane, przekręcają i niszczą? W czymże można dojrzeć rozsądne motywy tych przeróbek? Bo jeśli poprawianie na lepsze jest rzeczą zbożną i dla wielu pożyteczną to natomiast z pewnością wielką będzie zbrodnią przekręcanie czegoś na gorsze ${ }^{39}$.

Powołuje się także na autorów starożytnych, wskazując, że zarówno Cyceron, jak i Augustyn pisali, iż ludzie mniej wykształceni starają się poprawiać teksty osób posiadających zdecydowanie większą wiedzę.

${ }^{38}$ Ratio studiorum. Ustawa szkolna Towarzystwa Jezusowego, red. K. Bartnicka, Warszawa 2000, s. 40.

${ }^{39}$ Antonii Possevini Societatis Iesu Bibliotheca selecta de ratione studiorum, qua agitur de ratione studiorum in historia, in disciplinis, in salute omnium procuranda, Romae: Ex typographia Apostolica Vaticana 1593, s. 60. 
Odwołania do starożytnych pisarzy mogłyby dziwić w kontekście wykształcenia A. Possevina, a szczególnie jego przynależności do Towarzystwa Jezusowego. W konstytucjach zakonu napisano bowiem w odniesieniu do tworzenia publikacji, iż

tych zaś nie będzie można wydawać bez zatwierdzenia i zgody Przełożonego Generalnego, który niech poleci, by je przeczytały przynajmniej trzy osoby odznaczające się w danej dziedzinie zdrową nauką i zdrowym sądem ${ }^{40}$.

Autor Bibliotheca selecta w latach 80. XVI wieku miał coraz większe problemy z cenzorami własnych druków. Świadczy o tym np. skarga Jakuba Wujka (1541-1597) w liście do generała Towarzystwa na A. Possevina, który zmuszał do akceptowania i niepoprawiania jego książki Notae divini verbi et apostolicae ecclesiae fides (ostatecznie ukazała się w 1586 r. w Poznaniu) ${ }^{41}$. Tłumacz Biblii sugerował generałowi, że jeżeli nie uda się przekonać jezuity teraz, to należy zająć się publikacją tuż po jej wydrukowaniu i poddać ją ostrej wewnętrznej cenzurze ${ }^{42}$. Konsekwencją działań Wujka było cofnięcie uprawnień legata dla zakonnika i wysłanie go do Braniewa.

\section{Pierwsze thumaczenie Cultura ingeniorum na język polski}

Doktor Zofia Krystyna Remerowa (1898-1986) w ramach swoich prac z tekstami łacińskimi przygotowywała do opublikowania źródłowego wydaną w Wenecji w 1604 r. część dzieła Antonio Possevina SJ Cultura ingeniorum z Bibliotheca selecta. Tłumaczka pracy nie ukończyła. Zostały pominięte wstępne i końcowe fragmenty tekstu, w tym dedykacja pamięci prymasa Stanisława Karnkowskiego. Maszynopis sporządzony - sadzę, że ponad czterdzieści pięć lat temu - znalazł się w zasobach Biblioteki Wydziału Dziennikarstwa, Informacji i Bibliologii Uniwersytetu Warszawskiego i będzie przygotowywany do publikacji w kolejnym roku wraz z całym aparatem krytycznym, którego nie ma w zachowanym materiale. Tłumaczenie K. Remerowej, której doświadczenie w wielu innych przedsięwzięciach edytorskich ${ }^{43}$ zostało docenione przez wydawnictwa naukowe, jest bardzo dobre i warte zaprezentowania badaczom w języku polskim.

${ }^{40}$ I. Loyola, Konstytucje Towarzystwa Jezusowego wraz z przypisami Kongregacji Generalnej XXXIV oraz normy uzupetniajace zatwierdzone przez tę sama Kongregacje, Kraków-Warszawa 2006, s. 121.

${ }^{41}$ Była przedrukowana w XVI wieku jeszcze dwukrotnie w Moskwie. Zob. C. Mazur, S. Kalinkowski, Biuletyn patrystyczny, „Collectanea Theologica”, 53 (1983) nr 1, s. 133-134.

${ }^{42}$ Jakub Wujek do Claudio Aquaviva 9 V 1585, w: Korespondencya księdza Jakóba Wujka z Wagrowca z lat 1669-1596, podtug autografów, wyd. J. Sygański, „Roczniki Towarzystwa Przyjaciół Nauk Poznańskiego", 46 (1920), s. 46-47.

${ }^{43}$ Zob. Św. Augustyn, Wyznania, tłum. i wstęp K. Wisłocka-Remerowa, Kraków 1929, Biblioteka Narodowa, Seria 2; Marek Tuliusz Cyceron, Wybór pism naukowych, tłum. z jęz. łac. K. Wisłocka-Remerowa, wstęp i oprac. M. Plezia, Wrocław 1954, Biblioteka Narodowa, Seria 2, potem wznawianie np. Wydawnictwa: De Agostini, Ediciones Altaya Polska, 2002, Arcydzieła Wielkich Myślicieli, 2006, Arcydzieła Kultury Antycznej; Jan Amos Komeński, Pisma wybrane, tłum. K. Remerowa; wybór, wstęp, koment. B. Suchodolski, Wrocław 1964, Biblioteka Klasyków Pedagogiki. Pisarze Obcy; Jan Amos Komeński, Wielka dydaktyka, tłum. z jęz. łac. K. Remerowa, wstęp i koment. B. Sucho- 


\section{Zakończenie}

Przedstawione tezy zostaną rozwinięte we wstępie do wydania krytycznego Cultura ingeniorum, po dogłębnej analizie wszystkich zasygnalizowanych wcześniej wątków. Całość będzie odpowiedzią, mam nadzieję, sceptykom, ale i entuzjastom jezuickich metod wychowania młodzieży, na podstawowe pytanie - jak dalece można kształtować sylwetkę, w tym umysł młodego człowieka i co jest manipulacją, a co nowoczesnym na owe czasy podejściem do edukacji, dopuszczającym odhumanizowanie i mistycyzowanie literatury oraz kultury traktowanych jako oręże Kościoła walczącego z reformacją. W przekonaniu o celowości nieustannego uzupełniania źródeł warsztatu historyków zajmujących się kontrreformacją przedstawię tekst, o walorach którego można dyskutować, jest jednak interesującą wypowiedzią znakomitego przedstawiciela Kościoła na tematy ważne na miarę końca XVI wieku.

W postulaty badawcze uzupełniające aktualną wiedzę wpisuję potrzebę dokonania pełnej analizy systemu szkolnictwa jezuickiego, poczynając od porównania Ratio studiorum z Bibliotheca selecta, a zwłaszcza Cultura ingeniorum oraz wykonanie szczegółowej inwentaryzacji, być może digitalizacji materiałów dotyczących Antonio Possevina SJ w zasobie repertoriów Papieskiego Instytutu Studiów Kościelnych w Rzymie.

\section{REFERENCES / BIBLIOGRAFIA}

\section{Źródła}

Antonii Possevini Societatis Iesu Bibliotheca selecta de ratione studiorum, qua agitur de ratione studiorum in historia, in disciplinis, in salute omnium procuranda, Romae: Ex typographia Apostolica Vaticana 1593.

Loyola Ignacy, Konstytucje Towarzystwa Jezusowego wraz z przypisami Kongregacji Generalnej XXXIV oraz normy uzupetniajace zatwierdzone przez tę sama Kongregacje, Kraków-Warszawa 2006.

Loyola Ignacy, Pisma wybrane. Komentarze, t. 1, oprac. M. Bednarz SJ, współpr. S. Filipowicz SJ, R. Skórka SJ, Kraków 1969.

Ratio atque institutio studiorum SJ, czyli Ustawa szkolna Towarzystwa Jezusowego (1599), wstęp i oprac. K. Bartnicka, T. Bieńkowski, Warszawa 2000.

Św. Hilary z Poitiers, De Trinitate. I. VII. 4. Patrol. Lat. X. 202. Cyt. za: „Wiadomości Archidiecezjalne Warszawskie", 17 (1927) nr 1, s. 15, http://mbc.cyfrowemazowsze.pl/ Content/63135/00068107-Wiadomosci\%20Archidiecezjalne\%20warszawskie\%20 1927\%20nr\%201-P1873.pdf (dostęp: 24.03.2020).

\section{Opracowania}

Antonio Possevino SJ (1533-1611). Życie i dzieło na tle epoki, red. D. Quirini-Popławska, Kraków 2012.

dolski, Wrocław 1956, Biblioteka Klasyków Pedagogiki. Pisarze Obcy; Jan Amos Komeński, Pampaedia, tłum. K. Remerowa, wstęp i koment. B. Suchodolski, Wrocław 1973, Biblioteka Klasyków Pedagogiki. Pisarze Obcy. 
Bacon Francis, Novum Organum, [Księga pierwsza] aforyzmów o tłumaczeniu przyrody i o królestwie człowieka, https://sady.up.krakow.pl/filnauk.bacon.norganum.htm (dostęp: 25.10.2021).

Balsamo Luigi, Antonio Possevino S.I. bibliografo della Controriforma e diffusione della sua opera in area anglicana, Firenze 2006.

Bangert William V., A History of the Society of Jesus, Saint Louis 1986.

Bielak Alicja, Symbolica vitae Christi meditatio Tomasza Tretera jako siedemnastowieczna realizacja emblematycznych medytacji. Źródła graficzne i zamysł zbioru, „Terminus", 20 (2018) z. 4 (49), s. 411-462.

Bieńkowski Tadeusz, „Bibliotheca selecta de ratione studiorum” Possewina jako teoretyczny fundament kultury kontrreformacji, w: Wiek XVII - kontrreformacja - barok. Prace z historii kultury, red. J. Pelc, Wrocław 1970, s. 291-307.

Budzyński Józef, Paideia humanistyczna, czyli wychowanie do kultury. Studium z dziejów klasycznej edukacji w gimnazjach XVI-XVIII wieku (na przykładzie Śląska), Częstochowa 2003.

Dąbkowska-Kujko Justyna, Jezuicka paideia, https://www.kul.pl/files/268/dabkowska_kujko jezuicka paideia.pdf (dostęp: 25.10.2021).

Dorigny Jean, La vie du Père Antoine Possevin de la Compagnie de Jésus, Paris 1712.

Dróżdż Andrzej, Antonio Possevino (SJ) i jego rozprawa „Cultura ingeniorum” (1598) o wychowywaniu młodzieży z dala od druków zakazanych, „Roczniki Biblioteczne”, 54 (2010) s. 3-23.

Fabre Pierre A., Rurale Flavio, The Acquaviva project. Claudio Acquaviva's generalate (1581-1615) and the emergence of modern catholicism, Boston 2017.

Fros Henryk, Święty Ignacy Loyola, Kraków 2001.

García García E., Alonso Miguel A., EL „,Examen de Ingenios” de Huarte de San Juan en la ,Bibliotheca Selecta” de Antonio Possevino, „Revista de Historia de la Psicología”, 25 (2003) nr 3-4, s. 387-396.

Gołębiowski Michał, Wpływ Ojców Kościoła na prozę staropolska przełomu XVI i XVII wieku. Analiza wybranych utworów, praca doktorska, UJ 2020, https://ruj.uj.edu.pl/ xmlui/bitstream/handle/item/276479/golebiowski_wplyw_ojcow_kosciola_na_proze staropolska_2020.pdf? sequence=1\&isAllowed=y (dostęp: 29.10.2021).

Górecki Artur, O jezuickiej Ratio studiorum, „Christianitas”, (2014) nr 58, s. 58-69.

Hofmann Albert, Antonio Possevinos Bemühungen um die sogenannten Nordischen Päpstlichen Seminare 1578-1585, Koblenz 1929.

Jaeger Werner, Paideia. Formowanie człowieka greckiego, Warszawa 2001.

Jarosz Irena, Ksiązki szkolne w Polsce w wieku XVI. Zarys problematyki, ,,Rozprawy z Dziejów Oświaty”, 21 (1978) s. 3-14.

Karttunen Lissi, Antonio Possevino. Un diplomate pontifical au XVIe siècle, Lausanne 1908.

Korespondencya księdza Jakóba Wujka z Wagrowca z lat1669-1596, podtug autografów, wyd. J. Sygański, „Roczniki Towarzystwa Przyjaciół Nauk Poznańskiego” 1920, t. 46, S. $1-110$.

Kuran Magdalena, Rola szkolnictwa jezuickiego w kształtowaniu wspólnoty europejskiej, „Acta Universitatis Lodziensis. Folia Litteraria Polonica”, 13 (2010) s. 35-44.

Kuźmina Dariusz, Ksiązka religijna w czasach reformacji i kontrreformacji $w$ Rzeczypospolitej XVI i XVII w., „Studia Ełckie”, 8 (2006) s. 153-161.

Kuźmina Dariusz, Piśmiennictwo jezuitów w XVI wieku w Polsce, w: Bibliologia polityczna, praca zbiorowa, red. D. Kuźmina, Warszawa 2011, s. 26-33. 
Litak Stanisław, Historia wychowania, t. 1: Do Wielkiej Rewolucji Francuskiej, Kraków 2004.

Litak Stanisław, Jezuici na tle innych zakonów męskich $w$ Polsce $w$ XVI-XVIII wieku, w: Jezuici a kultura polska. Materiały sympozjum z okazji jubileuszu 500-lecia urodzin Ignacego Loyoli (1491-1991) i 450-lecia powstania Towarzystwa Jezusowego (1540-1990), Kraków, 15-17 lutego 1991 r., red. L. Grzebień, S. Obirek, Kraków 1993, s. 185-198.

O’Malley John W., Pierwsi jezuici, oprac. J. Kołacz, F. Rzepka, Kraków 2007.

Mazur Czesław, Kalinkowski Stanisław, Biuletyn patrystyczny, „Collectanea Theologica”, 53 (1983) nr 1, s. 133-134.

Misztal Henryk, Cenzura uprzednia pism i druków w Kościele zachodnim (studium historyczno-prawne), Lublin 2001.

Muc Agata, Cenzura uprzednia w prawodawstwie kościelnym - zarys problematyki, „Bibliotheca Nostra", (2013) nr 2, s. 38-49.

Natoński Bronisław SJ, Szkolnictwo jezuickie w Polsce w dobie kontrreformacji, w: Z dziejów szkolnictwa jezuickiego w Polsce. Wybór artykułów, Kraków 1994, s. 34-62.

Nowicka-Jeżowa Alina, Pokolenia trydenckie między tradycja a wyzwaniami przyszłości, w: Formowanie kultury katolickiej $w$ dobie potrydenckiej. Powszechność i narodowość katolicyzmu polskiego, red. J. Dąbkowska-Kujko, Warszawa 2016, s. 21-31.

Obirek Stanisław, Antonio Possevino SJ i jego misja do Moskwy, „Nasza Przyszłość”, 89 (1998) s. 111-123.

Pastor Juan C., Juan Huarte. Badanie umystów do nauk, w: Klasycy psychologii. Wprowadzenie do studiów psychologicznych, oprac. H.E. Lück, R. Miller, G. Sewz-Vosshenrich, Kraków 2008, s. 9-16.

Petrani Aleksy, Reforma trydencka, „Prawo Kanoniczne”, 7 (1964) nr 3/4, s. 1-20.

Piechnik Ludwik SJ, Powstanie i rozwój jezuickiej Ratio Studiorum (1548-1599), Kraków 2003.

Piechnik Ludwik SJ, „Ratio studiorum”. Fundament działalności edukacyjnej i naukowej jezuitów, w: Wkład jezuitów do nauki i kultury w Rzeczypospolitej Obojga Narodów i pod zaborami, red. I. Stasiewicz-Jasiukowa, Kraków 2004, s. 69-90.

Polčin Stanislas, Une tentative d'Union au XVIe siècle. La mission religieuse du Père Antoine Possevin S.J. en Moscovie, Rome 1957.

Prejs Marek, Humanizm potrydencki i nowy model kultury katolickiej (manieryzm czy barok?), w: Humanistyczne modele kultury nowożytnej wobec dziedzictwa starożytnego, red. M. Prejs, Warszawa 2010, s. 153-175. 


\title{
THE BATTLE FOR SOULS IN CULTURA INGENIORUM OF ANTONIO POSSEVINO SJ
}

\begin{abstract}
The article announces and discusses the first Polish edition of Cultura ingeniorum, the work of Antonio Possevino SJ, based on the contemporary translation of this text by Krystyna Remerowa, from the edition of the first book of Bibliotheca selecta, from the year 1604. It focuses on historical contexts, describes main threads, announces controversies related (inter alia) to understanding of monastic censorship as a regulator of written communication. At the turnout of the 16th and 17th centuries father Possevino was a participant of the historical events that turned the path of history, mostly the picture of the society of that time. He wanted to influence these changes by (among others) adequate (in his opinion) and recommended (by the Society of Jesus), particularly after the Trident Council, orientation of the youth, their education with carefully selected reading and physical exercises, development (paideia) of talents as far as possible, always for God's glory. In this perspective, it can be interpreted in the perspective of media education paradigms. The article presents Possevino's work as the one reflecting dilemmas of that time, resulting also from the orders of the controversial church and monastic authorities. This is the text of the spiritually mature author, convinced about doing right things, sometimes supporting counter reformation absolutely.
\end{abstract}

Keywords: censorship; book; media education; reformation; the Society of Jesus

Translated by Matgorzata Kisilowska 